\title{
The unbearable rightness of two-ball fetch
}

\author{
Cite as: CMAJ 2019 July 8;191:E766-7. doi: 10.1503/cmaj.190213
}

CMAJ Podcasts: audio reading at https://soundcloud.com/cmajpodcasts/190213-enc

t was about 4 am on a night shift early in my career and I was struggling to keep my eyes open when a nurse came to me asking for help at triage. It was a bit of an unusual request, but I welcomed the chance to get up from the nursing station where I was attempting to catch up on a pile of incomplete charts. At triage, I found a middle-aged couple sitting at the desk, the woman looking impatient and the man, doleful. I was unclear initially as to why the nurse had asked for my help when I noticed that the guy was sobbing while the woman I presumed to be his wife reached over to rub his back. A big, well-groomed golden retriever, until then hidden from view by the counter, was coaxed onto a chair beside them. The dog was coughing and gagging.

"Hi there," I said, "what's happened?"

"She's choking," the woman said. The man seemed too broken up to speak.

I looked at the great furry head of the retriever and she opened her mouth very wide, allowing a clear, unimpeded view of incisors, wolfishly large canines, premolars and molars. She then gagged and coughed, which increased the volume of weeping of her human champion.

"We're worried she's got something stuck in her throat. She was chewing on a stick before this began," the man managed to say. I caught a whiff of metabolized beer breath.

I liked dogs well enough, sure, but I had never had one as a pet. I was slightly mystified by the man's distress. "Have you been drinking tonight?" I asked.

"Don't worry, I drove," said the woman, "And I haven't been."

"Oh, okay, good. Listen, you do realize that this is an emergency department? Meaning for two-legged creatures of the human variety."

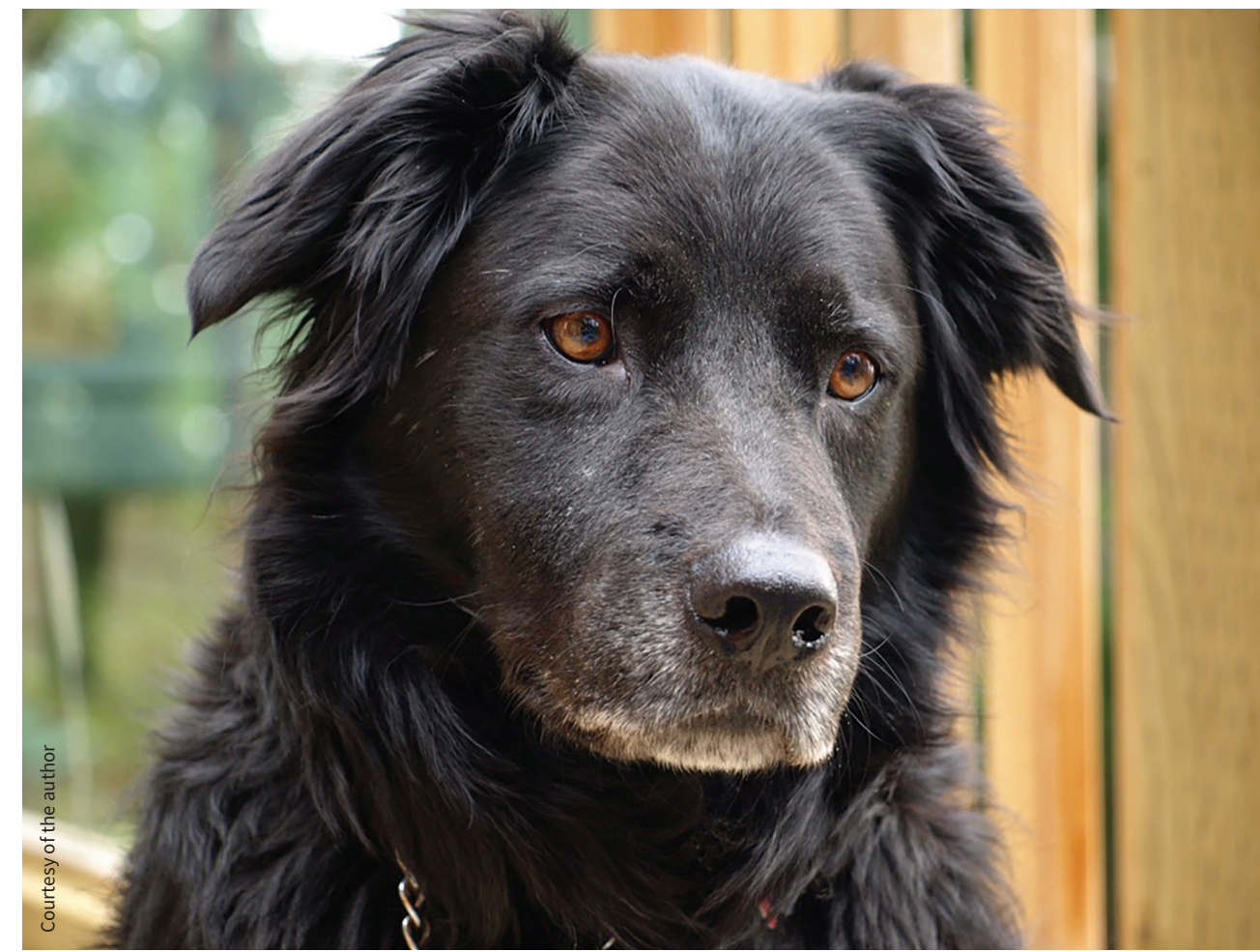

Casper

"Yes, we know, we know, doc," he replied. "But we were camping up by the lake, and we didn't know where to find an animal hospital, so we followed the signs with a capital $\mathrm{H}$ here. Look, we're desperate. Can't you have a look? What if she dies?"

I forced my eyes not to roll and asked the nurse to direct the couple to the veterinary hospital down the road. I walked away, feeling an urge to complete the charting I had left unfinished. We later heard that a foreign body had been easily removed from the retriever's pharynx.

Several years later, my wife brought home a black, long-haired Labrador Retriever-Border Collie cross with patches of white on his chest and paws. Someone, without having to work too hard, had talked her into adopting him. My wife had grown up with a succession of Labradors and Irish setters, and so she was a pushover for this fully grown pooch. He came prenamed: Casper. I was by then midcareer, working the full gamut of shifts that left me with just enough energy to help raise our four children and not much else. I wasn't sure if bringing a dog into the mix was a good idea.

"Oh, come on. He'll be great for us, all of us," my wife said to me.

"All of us?" I said.

"Yes, all of us, you included. And a dog can take a teenager out of her selfabsorbed bubble. He's a beauty, noble, almost. Look at those eyes!" She said, "I see both sadness and loyalty." 
"Nice looking dog, I grant you. And the kids will love him, I'm sure, but it will be you and me doing all the work."

"And you won't mind doing it for him. Because with dogs there is just as much give as take. Maybe more. Believe me, you'll see."

I relented, and Casper entered our lives. He immediately identified me as the one he would follow to the ends of the earth or, failing that, at least to the bathroom. It was clear, even though my wife had brought him home, he was my dog. I found him needy at first, but I took this characteristic to signal a rejection complex, given I was not his first master. But slowly over time, I began to experience his drive for a close connection not as a fault but as an attribute.

Not to say that he didn't have a few quirks. He expressed his stress through a lopsided grin that always struck me as both funny and touching. But one could easily relieve his anxiety with a trip outdoors to pursue his favourite activity, playing fetch.

He loved to chase a ball, but one wouldn't do. He would peel off after the tennis ball I would launch with the plastic ball-thrower, always bringing it back to me. But I could never convince him of the necessity of dropping it. Unless, that is, I rifled a second one through the air, forcing him to drop the first before giving chase. This became our daily routine.

Foibles and all, he had grown on me; in fact, I began to wonder how I had made it so far in life without a dog. He was there for me when I was sleep deprived and miserable after a string of night shifts.
Upon completing my final night duty of a rotation, I would deliberately shortchange myself of sufficient sleep during the day of transition to readjust and be able to sleep that evening. I would be melancholic and irritable during those times, unfit for human fellowship. But in Casper I found a calming presence. He accompanied me everywhere, soothing my jangled nerves on long walks in the forest or by the water's edge. He was a buddy, a companion, who asked nothing of me but my mostly wordless company.

He'd been with us then for seven or eight years when one day, as he walked ahead of me, I noticed a moderately large swelling under and to the side of his tail. A little research helped us decide that it was likely an anal gland carcinoma, later confirmed by our vet. It was not curable.

We had nearly another year with him. He continued to find joy in chasing balls, romping with other dogs and, of course, hanging out with me. But the day came when he simply could not defecate attempt after attempt he would make, would, in fact, tremble and fall over with the strain of trying. It got to be wholly pathetic. I couldn't deny that the tumour had grown remarkably large. It was time.

I eased Casper out of the back of the car and walked him into the vet's clinic. He sat beside me in the waiting room, his calm, trusting demeanour amplifying my own inner wretchedness. I reached over to pat him, as the veterinary assistant called out his name.

"We'll take him in now, sir. Come in, both of you."
In an examining room, on a comfortable carpet, Casper's stilled body was peaceful in repose, his great final sleep. The team had retreated, taking their syringes and vials to leave me to spend a few minutes with my dog's now lifeless carcass. Sniffling, I petted him one final time and said goodbye to my four-legged companion. "Tough-guy ER docs don't cry," I repeated silently on leaving the clinic.

By myself in the car in the parking lot, I had a flashback to my early career when a lack of empathy allowed me to dismiss a man's fears for his dog. I felt shame for my compassion deficiency, for the careless way in which I had linked the smell of beer on his breath to what I considered to be exaggerated emotion. Now, a dog who had unexpectedly entered and enriched my own life was gone.

I thought of our hours spent playing fetch together. I imagined launching one final ball for him. It sailed high and far out of sight. I pictured Casper chasing it into the horizon, only he didn't come back for the second one.

I wiped tears from my eyes on the lonely drive home.

\section{Brian Deady MD}

Emergency Department, The Royal

Columbian Hospital, New Westminster, BC; Department of Emergency Medicine, University of British Columbia, Vancouver, BC

This article has been peer reviewed.

This is a true story, although it happened more than 20 years ago. 